\title{
Zooplankton communities in a river downstream from a lake restored with hypolimnetic withdrawal
}

\author{
Magdalena Bowszys ${ }^{1, *}$, Renata Tandyrak ${ }^{2}$, Iwona Gołas ${ }^{3}$ and Ewa Paturej ${ }^{1}$ \\ ${ }^{1}$ Department of Tourism, Recreation and Ecology, University of Warmia and Mazury, Oczapowskiego 5, 10-957 Olsztyn, Poland \\ ${ }^{2}$ Department of Water Protection Engineering, University of Warmia and Mazury, Prawocheńskiego 1, 10-957 Olsztyn, Poland \\ ${ }^{3}$ Department of Environmental Microbiology, University of Warmia and Mazury, Prawocheńskiego 1, 10-957 Olsztyn, Poland
}

Received: 31 July 2019 / Accepted: 1 February 2020

\begin{abstract}
Restoring lakes with hypolimnetic withdrawal can severely threaten water quality and biocenosis downstream. The objective of this study was to evaluate the effect of lake restoration on riverine zooplankton during a period of intense hypolimnion water inflow. Zooplankton density and biomass were determined in water samples. The water samples were also analyzed to determine the following physicochemical parameters: flow rate, dissolved oxygen, hydrogen sulphide, sulphate, ammonium nitrogen, nitrate nitrogen, total phosphorous, soluble reactive phosphorus, total organic carbon, and temperature. The results of multiple regression indicated that water flow was the most significant variable and was the best predictor of total zooplankton and rotifer density. Soluble reactive phosphorous was the main predictor of copepod biomass and density. Our study showed that hypolimnetic withdrawal disturbed the natural process of planktic community transformation, which was linked to the environmental shift from lacustrine to riverine. During the study, zooplankton density and biomass were low, but not as low as when the pipeline was operating at maximum output. At present, this lake restoration method has become more sustainable, because the adverse effects of hypolimnetic withdrawal on the recipient river have been minimized and limited to several weeks.
\end{abstract}

Keywords: Lake restoration / recipient river / Rotifera / Copepoda / Cladocera

Résumé - Communautés de zooplancton dans une rivière en aval d'un lac restauré grâce à un retrait hypolimnique. La restauration des lacs par prélèvement hypolimnique peut gravement menacer la qualité de l'eau et la biocénose en aval. L'objectif de cette étude était d'évaluer l'effet de la restauration d'un lac sur le zooplancton aval pendant une période d'apport d'eau hypolimnique intense. La densité et la biomasse du zooplancton ont été déterminées dans des échantillons d'eau. Les échantillons d'eau ont également été analysés pour déterminer les paramètres physicochimiques suivants : débit, oxygène dissous, sulfure d'hydrogène, sulfate, azote d'ammonium, azote de nitrate, phosphore total, phosphore réactif soluble, carbone organique total et température. Les résultats d'une régression multiple ont indiqué que le débit était la variable la plus significative et était le meilleur prédicteur de la densité totale du zooplancton et des rotifères. Le phosphore réactif soluble était le principal prédicteur de la biomasse et de la densité des copépodes. Notre étude a montré que le retrait hypolimnique perturbait le processus naturel de transformation des communautés planctoniques, qui était lié au passage de l'environnement lacustre à l'environnement fluvial. Au cours de l'étude, la densité et la biomasse de zooplancton étaient faibles, mais pas autant que lorsque le pipeline fonctionnait à son rendement maximum. À l'heure actuelle, cette méthode de restauration des lacs est devenue plus supportable, car les effets néfastes du prélèvement hypolimnique sur la rivière réceptrice ont été minimisés et limités à plusieurs semaines.

Mots clés : Restauration de lac / rivière réceptrice / Rotifère / Copépode / Cladocère

\footnotetext{
*Corresponding author: mbowszys@uwm.edu.pl
} 


\section{Introduction}

Lake restoration is implemented in degraded waterbodies to re-establish close to pristine or at least anthropogenically undisturbed conditions. Many technical and biological methods of lake restoration are applied; hypolimnetic water withdrawal is one such method that has been applied in numerous lakes worldwide (e.g., Marshall et al., 2006; Nürnberg, 2007, Kumar, 2008; Lehman et al., 2009). This method was first applied in 1956 in Lake Kortowskie. A weir was constructed to elevate the water level in the lake and to reduce surface water outflow into the Kortówka River. This enabled syphoning the hypolimnion waters trough a pipeline up to the surface and discharging them into the river (Olszewski, 1971). The results of restoring Lake Kortowskie with hypolimnetic water withdrawal are discussed in many papers (e.g., Dunalska, 2001; Dunalska, 2003; Dunalska et al., 2007; Jaworska et al., 2014a,b). The method applied achieved positive effects by removing nutrients from the lake hypolimnion over a long period of time. At present, the experiment aims at removing the nutrient rich bottom layers, i.e., the entire volume of the hypolimnion, in as short a period of time as possible.

Despite this technique having been used on several dozen lakes to date (Nürnberg, 1987; Kumar, 2008, Dunalska, 2007, and references therein), the effect of hypolimnetic withdrawal on downstream water quality has received little attention. High ammonia and phosphorous concentrations in hypolimnion waters, low dissolved oxygen content, and high hypolimnetic hydrogen sulphide are expected and constitute the main threats to downstream ecosystems. Very high hydrogen sulphide concentrations can also generate significant nuisance odours in the vicinity of rivers. Therefore, Nürnberg $(1987,2007)$ suggested treating hypolimnetic waters before discharging them into recipient rivers, especially small ones.

The implementation of the Water Framework Directive requires good ecological and chemical status of waters. Nonintrusive lake restoration methods are recommended to meet Directive requirements (Gołdyn et al., 2014). Such methods should be easy to use, effective, sustainable, and not harmful to riverine biota. Therefore, the effect of hypolimnetic withdrawal lake restoration on the quality of downstream rivers must be investigated more thoroughly. Tandyrak et al. (2016) were the first to attempt a complex assessment of the effect of lake restoration on a recipient river and its surroundings. The authors demonstrated that the hypolimnetic water inflow negatively affected the physicochemical properties of the water. The study also revealed that when hypolimnion water withdrawal was intense the odours released by hypoxic waters affected not only the immediate vicinity of the river, but also adjacent recreational areas.

The violent disruption of natural lake-river system continuity can also be harmful to organisms and exert a negative impact on downstream biocenosis. Although Lake Kortowskie has been studied extensively throughout the experiment (e.g., Olszewski, 1971; Mientki, 1997; Dunalska, 2001; Dunalska, 2003; Jaworska et al., 2014), little information is available on the impact lake restoration has on the biocenosis of the river receiving hypolimnetic waters, and only scant information on algae (Chudyba, 1996) and selected bottom-associated taxa (Pietrzak, 2004) is available. To date, no data has been published on the zooplankton community in the Kortówka River, nor is there any data in the literature on the impact lake restoration has on downstream zooplankton. Significant organic matter pollution, high oxygen demand and associated oxygen depletion, high hydrogen sulphide concentrations, and low temperatures (Tandyrak et al., 2016) are the main factors that can negatively affect zooplankton communities in the Kortówka River. The hypolimnetic water discharge of this restoration method can cause low zooplankton abundance. Operating the pipeline discharges deep lake water layers that are naturally poor in zooplankton into the river. Moreover, the hydrological regime of the lake limits the partial outflow of surface waters to the river (Dunalska, 2007), which are richer in planktic organisms. Additionally, when the surface layers of the lake, meet oxygen-depleted, cold hypolimnion waters, the organisms carried by surface flow are exposed to physiological stress that can lead to reductions in their numbers.

The aim of the present study was to determine the impact lake restoration with hypolimnion withdrawal had on riverine zooplankton development during intense hypolimnion water inflow into the recipient river. To better understand this effect, the following questions were addressed: (1) what was the quantitative and qualitative composition of zooplankton in the river? (2) Did zooplankton abundance and biomass change significantly in the river? (3) Did hydrological and physicochemical factors have significant impacts on riverine zooplankton communities?

\section{Materials and methods}

\subsection{Study area and collection of samples}

The Kortówka River flows through Lake Kortowskie, which is located in north-eastern Poland (latitude - 53 $45^{\prime} 43^{\prime \prime}$; longitude $\left.-20^{\circ} 26^{\prime} 42^{\prime \prime}\right)$, within the administrative limits of the town of Olsztyn. The lake has been restored by the method of hypolimnetic water withdrawal (Olszewski, 1971). A pipeline was constructed to enable bottom water and biogenic compounds discharge to the Kortówka River. The inlet of the pipeline is located at a depth of $17.2 \mathrm{~m}$, in the northern part of the lake. The outlet of the pipeline is situated at the site of the Kortówka River outflow from Lake Kortowskie (Fig. 1). A natural, surface inflow of lake water to the river was limited by the construction of a weir at the river outlet, which allowed hypolimnetic water evacuation. Thus, water that enters the river is a mixture of water from surface layers of the lake and bottom water that is supplied by the pipeline. In recent years, the efficiency of hypolimnion waters removal has been reduced due to unfavourable hydrological regime of the lake. At present, the period of time during which hypolimnetic withdrawal takes place is limited to $2-3$ months in a year (from summer water stagnation in July to the fall turnover in October). The water discharge from the pipeline depends mostly on natural conditions (hydrologic and atmospheric). The modification of the method did not affect the positive results of the lake restoration (Dunalska, 2001).

The present study was carried out in 2013, at the time of intense hypolimnetic withdrawal via the pipeline. Sampling was carried out from July to October, usually once-twice a 


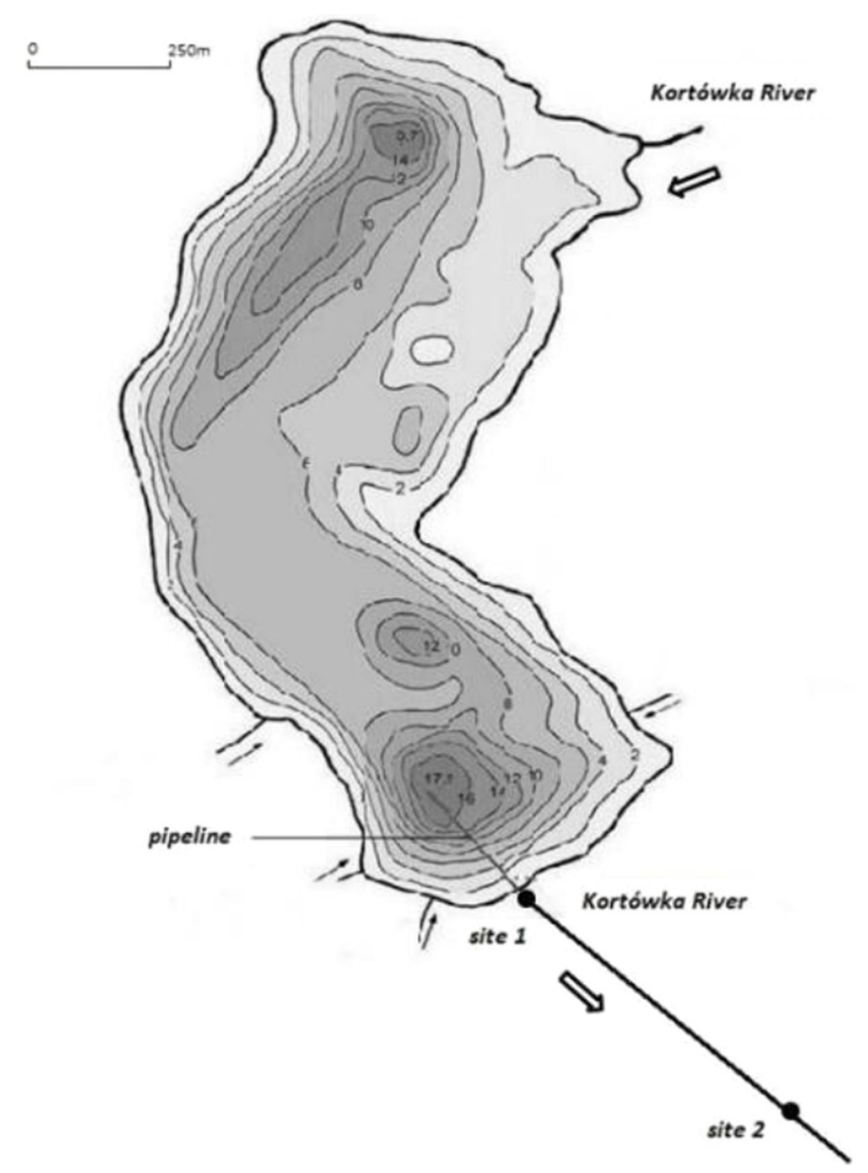

Fig. 1. Study area and sampling site locations in the Kortówka River.

week. Zooplankton and water were sampled at two sites (Fig. 1). Site 1 was located at an estimated distance of $2 \mathrm{~m}$ from the outlet of the pipeline discharging water from Lake Kortowskie to the Kortówka River. Site 2 was located at an estimated distance of $500 \mathrm{~m}$ from site 1 . The distance between sites was determined based on the presence of unpleasant odour released from bottom waters, which was clearly detectable at the point of the pipeline outlet, and hardly noticeable $500 \mathrm{~m}$ downstream. The change of odour intensity identifies significant change of environmental conditions in the river. Water samples for zooplankton and physicochemical analyses were collected at the centre of the main river flow, at a depth of $20-30 \mathrm{~cm}$, with a $5 \mathrm{~L}$ bucket. For zooplankton analyses $25 \mathrm{~L}$ of water were taken at each sampling site and at each sampling event. A total of 64 samples were collected, including 32 zooplankton samples and 32 water samples. In order to analyse similarity between the zooplankton communities inhabiting the river (site 1) and the lake (epilimnion and hypolimnion), zooplankton samples were also taken from Lake Kortowskie on 18 July, 8 August, 7 September, and 1 October. The sampling site was located in the deepest part of the lake, at the place where the pipeline inlet is located. The water for zooplankton analyses was taken by a $5 \mathrm{~L}$ Patalas type sampler, from the water column, in epilimnion and hypolimnion layers separately, at $1-2 \mathrm{~m}$ intervals. In total, 8 samples were taken.

\subsection{Zooplankton analytical procedure}

The zooplankton samples of 25-30 L were concentrated to a volume of $30-50 \mathrm{~mL}$ by filtering them through a $30-\mu \mathrm{m}$ mesh. These were then preserved with Lugol's solution and fixed in a $4-5 \%$ formalin solution. For microscope analysis, three 1-mL subsamples were collected from each sample using an automatic pipette and placed in a Sedgewick Rafter counting chamber. Rotifers and planktonic crustaceans were classified by species (except for juvenile copepods). Zooplankton specimens were identified with a Zeiss Axio Imager microscope using the keys described by Flössner (1972), Koste (1978), Ejsmont-Karabin et al. (2004), Rybak and Błędzki (2010) and Błędzki and Rybak (2016). About 30 individuals of each species were measured to determine the body length by the Axio Vision software. The individual weights of rotifers were estimated from average lengths, according to RuttnerKolisko (1977) and Ejsmont-Karabin (1998). The lengths of crustaceans were converted to weights, according to Botrell et al. (1976). Finally, zooplankton abundance and biomass were calculated. Zooplankton dominance structure and constancy of occurrence were determined according to Kasprzak and Niedbała (1981) and Tischler (1949), respectively. A similarity of the zooplankton communities was evaluated by the Jaccard's index (Jaccard, 1912).

\subsection{Physicochemical analyses of water samples}

The following physicochemical parameters were analysed in samples collected from the river: dissolved oxygen, hydrogen sulphide, sulphate, nitrate nitrogen, ammonium nitrogen, soluble reactive phosphorus, total phosphorus, total organic carbon. Dissolved oxygen concentrations were determined by the Winkler's method, hydrogen sulphide levels - by iodometric titration, sulphate concentrations were measured in the Dionex-Hach ICS 3000 system. Ammonium nitrogen levels were determined in the Merck SQ118 photometer. Nitrate nitrogen (V) was measured in the NANOCOLOR spectrophotometer $(\kappa-435 \mathrm{~nm})$. Soluble reactive phosphorus was determined with ammonium molybdate and $\mathrm{SnCl}_{2}(\kappa-690 \mathrm{~nm})$ and total phosphorus (TP) after mineralization with $\mathrm{H}_{2} \mathrm{SO}_{4}$ and $\mathrm{K}_{2} \mathrm{~S}_{2} \mathrm{O}_{8}$ (as soluble reactive phosphorus). To determine the content of organic carbon, a sample was acidified to $\mathrm{pH} 2$ with $4 \mathrm{M} \mathrm{HCl}$, and inorganic carbon forms were removed by passing oxygen through the sample. The concentrations of non-volatile total organic carbon were determined by the HACH IL 550 TOC-TN analyser. Chemical analyses were performed according to standard methods (Clesceri et al., 1998; Hermanowicz et al., 1999) and Norm PN-EN 1484:1999. Water temperature was measured at sites during each sampling event using a YSI 6600 V2 Multi-Parameter Water Quality Sonde.

\subsection{Statistical procedures}

Statistical significance of the differences between sites in zooplankton abundance, biomass and physicochemical parameters was tested using $t$-test $(p<0.05)$. Correlation coefficients were calculated with the use of Spearman ranks $(p<0.05)$ to determine the relationship between environmental 
Table 1. Zooplankton species composition and mean density [indiv. $\mathrm{L}^{-1}$ ] at sites number 1 and 2 in the Kortówka River - only dominants and species of a high constancy of occurrence are shown.

\begin{tabular}{|c|c|c|c|c|}
\hline Zooplankton taxa & Site & Mean density (SD) & $D^{*}$ & $C^{* *}$ \\
\hline \multirow[b]{2}{*}{ Anuaeropsis fissa (Gosse, 1851) } & 1 & $32.1(36.9)$ & +++ & $\mathrm{xx}$ \\
\hline & 2 & $29.8(52.5)$ & +++ & $\mathrm{xx}$ \\
\hline \multirow[b]{2}{*}{ Ascomorpha ecaudis (Perty, 1850) } & 1 & $3.2(4.1)$ & & $\mathrm{x}$ \\
\hline & 2 & $3.6(2.9)$ & + & $\mathrm{xx}$ \\
\hline \multirow{2}{*}{ Ascomorpha ovalis (Bergendal, 1892) } & 1 & $2.7(2.6)$ & + & $\mathrm{xx}$ \\
\hline & 2 & $1.9(1.7)$ & & $\mathrm{x}$ \\
\hline \multirow{2}{*}{ Asplanchna priodonta (Gosse, 1850) } & 1 & $6.7(5.6)$ & + & $\mathrm{xx}$ \\
\hline & 2 & $5.5(6.1)$ & + & $\mathrm{xx}$ \\
\hline \multirow{2}{*}{ Keratella cochlearis (Gosse, 1851) } & 1 & $41.8(78.6)$ & +++ & $\mathrm{x}$ \\
\hline & 2 & $25.1(14.5)$ & +++ & $\mathrm{x}$ \\
\hline \multirow{2}{*}{ Keratella cochlearis var tecta (Gosse, 1851) } & 1 & $33.1(21.2)$ & +++ & $\mathrm{xx}$ \\
\hline & 2 & $25.2(14.5)$ & +++ & $\mathrm{xx}$ \\
\hline \multirow{2}{*}{ Polyarthra dolichoptera (Idelson, 1925) } & 1 & $18.4(13.1)$ & +++ & $\mathrm{xx}$ \\
\hline & 2 & $13.3(10.0)$ & ++ & $\mathrm{xx}$ \\
\hline \multirow[b]{2}{*}{ Polyarthra major (Burckhardt, 1900) } & 1 & $10.3(9.4)$ & ++ & $\mathrm{xx}$ \\
\hline & 2 & $8.3(6.7)$ & ++ & $\mathrm{xx}$ \\
\hline \multirow{2}{*}{ Proales sp. } & 1 & $1.7(0.8)$ & & \\
\hline & 2 & $6.4(6.4)$ & + & $\mathrm{xx}$ \\
\hline \multirow[b]{2}{*}{ Trichocerca pusilla (Lauterborn, 1898) } & 1 & $3.1(3.3)$ & $\cdot$ & $\mathrm{x}$ \\
\hline & 2 & $4.0(3.4)$ & + & $\mathrm{x}$ \\
\hline \multirow[b]{2}{*}{ nauplius } & 1 & $13.4(8.1)$ & ++ & $\mathrm{xx}$ \\
\hline & 2 & $11.0(9.1)$ & ++ & $\mathrm{xx}$ \\
\hline \multirow{2}{*}{ copepodite (Cyclopoida) } & 1 & $2.8(1.3)$ & $\cdot$ & $\mathrm{x}$ \\
\hline & 2 & $2.8(3.8)$ & . & $\mathrm{x}$ \\
\hline
\end{tabular}

${ }^{*}$ the level of species dominance $(D)$ is indicated as follows: ${ }^{+++}$eudominant; ${ }^{++}$dominant; ${ }^{+}$subdominant, recedent; ${ }^{* *}$ species occurrence constancy $(C)$ is indicated as follows: absolute species $x x$-mark; constant species $x$-mark.

variables and zooplankton abundance. The multiple stepwise regression was applied to find the best predictors for abundance of zooplankton. The percentage of variation explained by the pattern was based on $R^{2}$. To satisfy the assumptions of the normality in the data, all variables were $\log$-transformed. Statistical analyses were done with STATISTICA 13.0 .

\section{Results}

\subsection{Zooplankton composition and faunistic similarity}

During the study period, the occurrence of 40 zooplankton species was confirmed in the Kortówka River, the vast majority of which were rotifers. There were just three crustacean species: the cladoceran Bosmina longirostris, the copepods Mesocyclops leuckarti and Thermocyclops oithonoides, and their juvenile copepodite and nauplii forms. The eudominant zooplankton included the following: Anuaeropsis fissa; Keratella cochlearis; Keratella cochlearis var tecta; Polyarthra dolichoptera. These species were also the absolute permanent forms, which means they were characterized by the highest indexes of constancy of occurrence (Tab. 1).

The Jaccard index was calculated to compare faunistic similarity between the zooplankton communities in the
Table 2. Jaccard's similarity indices of zooplankton between the site in the Kortówka River located at the pipeline outlet and in the epilimnion and hypolimnion layers near the pipeline inlet in Lake Kortowskie. Abbreviations: KR - the Kortówka River; $\mathrm{LK}_{\text {epi }}$ - Lake Kortowskie epilimnion; $\mathrm{LK}_{\text {hypo }}-$ Lake Kortowskie hypolimnion, $\mathrm{Q}$ - flow rates in the river.

\begin{tabular}{llll}
\hline Date & $\mathrm{KR}-\mathrm{LK}_{\text {epi }}$ & $\mathrm{KR}-\mathrm{K}_{\text {hypo }}$ & $\mathrm{Q}\left[\mathrm{L} \mathrm{s}^{-1}\right]$ \\
\hline 18 Jul & 0.36 & 0.35 & 76.2 \\
8 Aug & 0.35 & 0.34 & 20.3 \\
7 Sept & 0.37 & 0.34 & 60.6 \\
1 Oct & 0.38 & 0.33 & 44.1 \\
\hline
\end{tabular}

Kortówka River and those inhabiting the epilimnion and hypolimnion of Lake Kortowskie; the values were similar and fluctuated with the range of $0.33-0.38$. Slightly higher values were noted when comparing the zooplankton of the Kortówka River and the community inhabiting the epilimnion of Lake Kortowskie. The generally low values of the faunal similarity coefficient indicated the slight faunistic similarity between the Kortówka River zooplankton community and that inhabiting the surface and near-bottom water layers in Lake Kortowskie (Tab. 2). 
Table 3. Mean and standard deviation (SD) of values of zooplankton density and biomass in water samples from sites 1 and 2 in the Kortówka River in 2013 and the significance of differences in parameter values between sites.

\begin{tabular}{llll}
\hline Zooplankton & \multicolumn{2}{c}{ Site } & $\begin{array}{l}\text { Difference }(P) \\
\text { between sites }\end{array}$ \\
\cline { 2 - 3 } & 1 & 2 & \\
\hline Total density & $175.2(93.4)$ & $148.6(77.5)$ & n.s. \\
Rotifera density & $158.9(91.6)$ & $133.3(73.5)$ & n.s. \\
Copepoda density & $16.3(9.0)$ & $14.3(11.7)$ & n.s. \\
Cladocera density & - & $1(0.9)$ & - \\
Total biomass & $0.267(0.143)$ & $0.231(0.506)$ & n.s. \\
Rotifera biomass & $0.168(0.123)$ & $0.142(0.126)$ & n.s. \\
Copepoda biomass & $0.089(0.051)$ & $0.079(0.046)$ & n.s. \\
Cladocera biomass & - & $0.010(0.021)$ & - \\
\hline
\end{tabular}

n.s. $=$ difference not significant $(t$-test $)$.

\subsection{Zooplankton abundance and biomass}

Studies of zooplankton abundance in the Kortówka River showed that there was only slight differentiation between sites 1 and 2 . The mean total zooplankton density was higher at site $1\left(175.2\right.$ indiv $\left.\mathrm{L}^{-1}\right)$ than at site $2\left(148.6\right.$ indiv $\left.\mathrm{L}^{-1}\right)$. The mean rotifer density was also higher at site 1 (158.9 indiv $\left.\mathrm{L}^{-1}\right)$ in comparison to that at site $2\left(133.3\right.$ indiv $\left.\mathrm{L}^{-1}\right)$. The differences observed were not statistically significant $(p>0.05)$. The mean density of copepods at the two sites was similar (Tab. 3 ). Zooplankton densities recorded in Lake Kortowskie were much higher. In July, the mean total zooplankton density in lake water was 1022 indiv L $^{-1}$; in August it was 1094.7 indiv $\mathrm{L}^{-1}$; in September it increased to 2088 indiv $\mathrm{L}^{-1}$; and in October it was 1510.2 indiv $\mathrm{L}^{-1}$.

The mean zooplankton biomass at site 1 was $0.267 \mathrm{mg} \mathrm{L}^{-1}$, which was nearly identical to the mean value at site 2 of $0.231 \mathrm{mg} \mathrm{L}^{-1}$ (Tab. 3). The different zooplankton groups also exhibited little variability in this respect. Slightly higher values of mean copepod and rotifer biomass were noted at site 1; however, the differences were not statistically significant $(p>0.05)$.

Distinct seasonal variations in zooplankton density and biomass were noted at the two sites in the Kortówka River. At site 1 zooplankton density varied within a range of 35.5 indiv. $\mathrm{L}^{-1}$ to 427 indiv. $\mathrm{L}^{-1}$. During the period studied, there were two distinct peaks in zooplankton abundance: one was in the second half of August (299.2 indiv. $\mathrm{L}^{-1}$ ) and the other was at the end of October $\left(427\right.$ indiv. $\left.\mathrm{L}^{-1}\right)$. An equally large range of variability in zooplankton abundance was noted at site 2 at a minimum of 43.5 indiv. $\mathrm{L}^{-1}$ and a maximum of 312.8 indiv. $\mathrm{L}^{-1}$. Peak zooplankton abundance was noted in the second half of July and in September (approximately 300 indiv. $\mathrm{L}^{-1}$ ). Minimal zooplankton density at both sites was noted in early August (Fig. 2).

Zooplankton biomass at site 1 in the Kortówka River fluctuated within a range of $0.06-0.56 \mathrm{mg} \mathrm{L}^{-1}$. The highest biomass at this site was noted in mid September. During the study period, zooplankton biomass at site 2 was within a

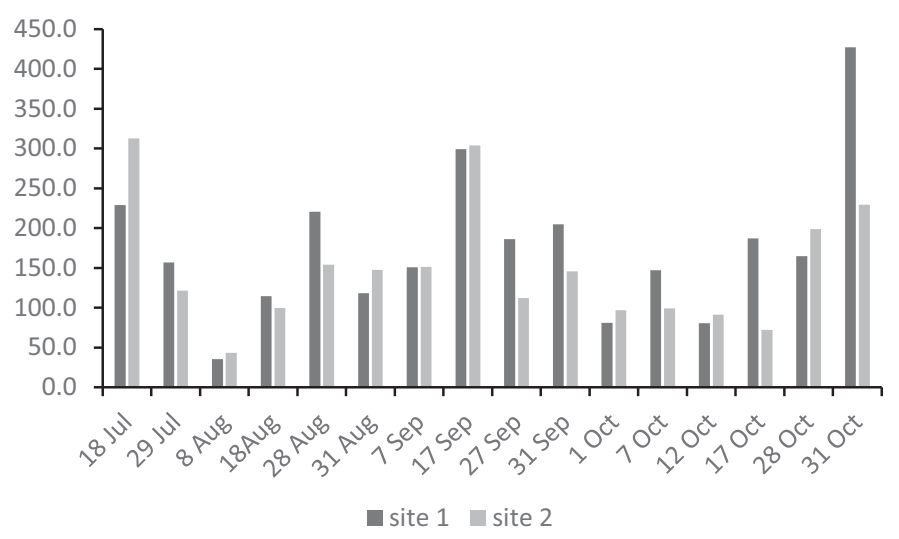

Fig. 2. Dynamics of change in zooplankton density [indiv. $\mathrm{L}^{-1}$ ] in the Kortówka River during hypolimnion water discharge from Lake Kortowskie in 2013.

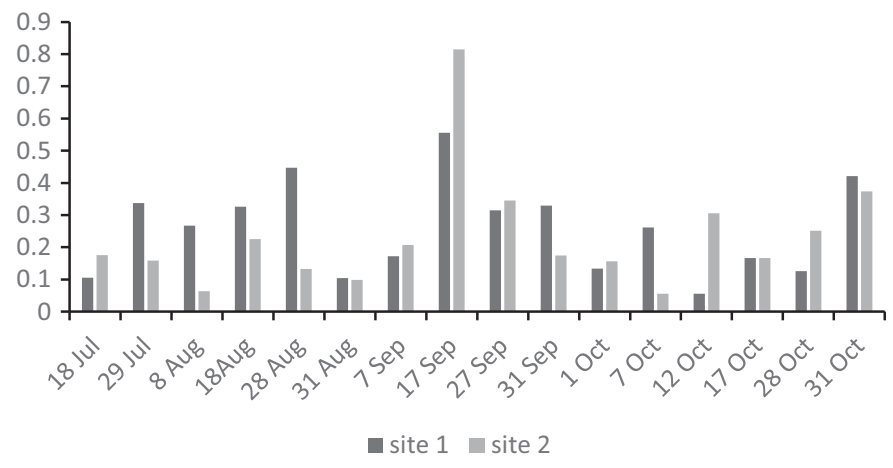

Fig. 3. Dynamics of change in zooplankton biomass $\left[\mathrm{mg} \mathrm{L}^{-1}\right]$ in the Kortówka River during hypolimnion water discharge from Lake Kortowskie in 2013.

similar range of $0.06-0.81 \mathrm{mg} \mathrm{L}^{-1}$. Maximum biomass values were also confirmed at this site in mid September (Fig. 3).

\subsection{Environmental parameters and their impact on zooplankton}

Significant fluctuations in river water flow rates were observed during hypolimnion water discharge from the lake to the Kortówka River (Fig. 4). Higher water flow rates of approximately $70.0-80.0 \mathrm{~L} \mathrm{~s}^{-1}$ were noted in the early part of the study period and also at the end of September. Distinct decreases in water flow rates in the river to approximately $10.0-20.0 \mathrm{~L} \mathrm{~s}^{-1}$ were observed on 8 and 18 August. Higher flow rates were generally noted at site 1 (the pipeline outlet) than at site 2 , but the difference was not statistically significant (test $t ; p>0.05$ ).

Significant variations in water properties were found between the sites (Tab. 4). The mean content of hydrogen sulphide in the water was higher at site 1 at $0.72 \mathrm{mg} \mathrm{L}^{-1}$ than at site 2 at $0.09 \mathrm{mg} \mathrm{L}^{-1}(t=3.24 ; p=0.0038)$. Similar variation was observed with sulphates, the mean of which was significantly higher at site 1 at $23.52 \mathrm{mg} \mathrm{L}^{-1}$ than at site 2 at $19.12 \mathrm{mg} \mathrm{L}^{-1}(t=2.65 ; p=0.019)$. Some of the parameters were characterized by increased levels in the water along with 
Table 4. Mean and minimum and maximum (in parentheses) values of physicochemical parameters in water samples collected at sites 1 and 2 in the Kortówka River in 2013 and the significance of differences in the values of the parameters noted between the sites. Abbreviations: DO dissolved oxygen; $\mathrm{H}_{2} \mathrm{~S}$ - hydrogen sulphide; $\mathrm{SO}_{4}$-sulphate; $\mathrm{NO}_{3}-\mathrm{N}$ - nitrate-nitrogen; $\mathrm{NH}_{4}-\mathrm{N}$ - ammonium nitrogen; $\mathrm{P}_{\text {tot }}-$ total phosphorus; $\mathrm{PO}_{4}-\mathrm{P}$ - soluble reactive phosphorus; TOC - total organic carbon; $\mathrm{T}-$ temperature.

\begin{tabular}{llll}
\hline Parameter & \multicolumn{2}{c}{ Site } & Difference (P) between sites \\
\cline { 2 - 4 } & 1 & 2 & n.s. \\
\hline $\mathrm{DO}[\mathrm{mg} \mathrm{L}-1]$ & $5.64(2.20-8.80)$ & $4.26(2.10-6.75)$ & $\mathrm{p}<0.01$ \\
$\mathrm{H}_{2} \mathrm{~S}\left[\mathrm{mg} \mathrm{L}^{-1}\right]$ & $0.72(0.00-1.87)$ & $0.09(0.00-0.34)$ & $\mathrm{p}<0.05$ \\
$\mathrm{SO}_{4}\left[\mathrm{mg} \mathrm{L}^{-1}\right]$ & $23.52(16.72-31.69)$ & $19.12(15.06-20.87)$ & $\mathrm{p}<0.05$ \\
$\mathrm{NH}_{4}-\mathrm{N}\left[\mathrm{mg} \mathrm{L}^{-1}\right]$ & $0.47(0.23-1.09)$ & $0.62(0.00-0.96)$ & $\mathrm{n} . \mathrm{s}$. \\
$\mathrm{NO}_{3}-\mathrm{N}\left[\mathrm{mg} \mathrm{L}^{-1}\right]$ & $0.05(0.01-0.08)$ & $0.07(0.03-0.09)$ & $\mathrm{p}<0.05$ \\
${\mathrm{P} \text { tot }\left[\mathrm{mg} \mathrm{L}^{-1}\right]}_{\mathrm{PO}_{4}-\mathrm{P}\left[\mathrm{mg} \mathrm{L}^{-1}\right]}$ & $0.30(0.18-0.57)$ & $0.49(0.24-0.55)$ & n.s. \\
$\mathrm{TOC}\left[\mathrm{mg} \mathrm{L}^{-1}\right]$ & $0.15(0.06-0.25)$ & $0.23(0.16-0.32)$ & n.s. \\
$\mathrm{T}\left[{ }^{\circ} \mathrm{C}\right]$ & $11.22(9.76-12.91)$ & $10.76(9.43-12.01)$ & $16.2(10.5-18.6)$ \\
\hline
\end{tabular}

n.s. $=$ difference not significant $(t$-test $)$.

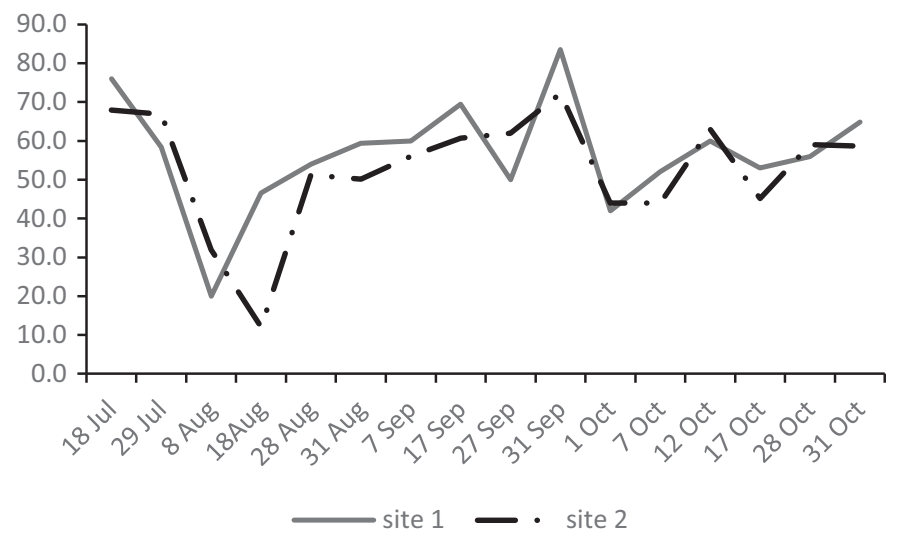

Fig. 4. Variability of water flow $\left[\mathrm{L} \mathrm{s}^{-1}\right]$ in the Kortówka River at study sites in 2013 during hypolimnion water discharge from Lake Kortowskie.

increased distance from the pipeline outlet. Higher mean concentrations of the following were noted at site 2 than at site 1: ammonium nitrogen $(t=2.50 ; p=0.02)$ at $0.62 \mathrm{mg} \mathrm{L}^{-1}$ and $0.47 \mathrm{mg} \mathrm{L}^{-1}$ respectively; total phosphorus $(t=-2.09$; $p=0.048)$ at $0.49 \mathrm{mg} \mathrm{L}^{-1}$ and $0.30 \mathrm{mg} \mathrm{L}^{-1}$, respectively; soluble reactive phosphorus $(t=-3.07 ; p=0.005)$, at $0.23 \mathrm{mg} \mathrm{L}^{-1}$ and $0.15 \mathrm{mg} \mathrm{L}^{-1}$, respectively. No statistically significant differences were noted in the remaining parameters.

Spearman rank correlations indicated that five of the ten environmental variables analyzed were significantly correlated with zooplankton (Tab. 5). At site 2 a positive relationship was confirmed between total zooplankton and rotifer densities and water flow rate in the river. Copepod density and biomass were positively correlated with the content of total organic carbon and oxygen in the water and negatively correlated with the content of soluble reactive phosphorus. Copepod density was also negatively correlated with the river water content of hydrogen sulphide. The only correlation at site 1 was the negative relationship between total zooplankton biomass and the content of soluble reactive phosphorus.

The equations calculated of the multiple regression models, produced through stepwise variable selection,
Table 5. Significant Spearman's correlations between environmental variables and zooplankton. Abbreviations: Q - water flow; DO dissolved oxygen; $\mathrm{H}_{2} \mathrm{~S}$ - hydrogen sulphide; $\mathrm{PO}_{4}-\mathrm{P}-$ soluble reactive phosphorus; TOC - total organic carbon; Ntot, Nr, Ncp total zooplankton, Rotifera and Copepoda density, respectively; Btot, Bcp - total zooplankton and Copepoda biomass, respectively; Upper indices: ${ }^{*} p<0.05,{ }^{*} p<0.01,{ }^{* *} p<0.001-$ significance level; 1,2 site number.

\begin{tabular}{|c|c|c|c|c|c|}
\hline \multirow[b]{2}{*}{ Variable } & \multicolumn{5}{|c|}{ Coefficients } \\
\hline & Ntot & $\mathrm{Nr}$ & Ncp & Btot & Bcp \\
\hline $\mathrm{Q}$ & ${ }^{2} 0,709 *$ & ${ }^{2} 0,673 *$ & & & \\
\hline DO & & & ${ }^{2} 0,645^{*}$ & & ${ }^{2} 0,682 *$ \\
\hline $\mathrm{H}_{2} \mathrm{~S}$ & & & ${ }^{2}-0,609 *$ & & \\
\hline $\mathrm{PO}_{4}-\mathrm{P}$ & & & ${ }^{2}-0,864 * * *$ & ${ }^{1}-0,623^{*}$ & ${ }^{2}-0,764^{* *}$ \\
\hline TOC & & & ${ }^{2} 0,855 * *$ & & ${ }^{2} 0,709 * *$ \\
\hline
\end{tabular}

revealed that water flow and the contents of soluble reactive phosphorous, sulphate, hydrogen sulphide, and dissolved oxygen affected zooplankton abundance significantly (Tab. 6). The effects on zooplankton of the contents of soluble reactive phosphorous (the only variable that affected the zooplankton at both sites), hydrogen sulphide, and sulphates were negative. Other variables were positively correlated with zooplankton abundance and/or biomass. Analyses explained from 35\% to $74 \%$ of zooplankton abundance variability. Water flow was the most significant variable and was identified as the best predictor of total zooplankton and rotifer density. Soluble reactive phosphorous occurred to be the main predictor of copepod biomass and density.

\section{Discussion}

\subsection{Zooplankton composition and faunistic similarity}

The Kortówka River zooplankton were dominated by rotifers. The quantitative share of crustaceans, including 
Table 6. Significance of the effects of environmental variables on zooplankton abundance based on multiple regression (stepwise procedure) with the following dependent variables: Ntot, $\mathrm{Nr}, \mathrm{Ncl}, \mathrm{Ncp}$ - total zooplankton, Rotifera, Cladocera, and Copepoda density, respectively; Btot, $\mathrm{Br}, \mathrm{Bcl}, \mathrm{Bcp}$ - total zooplankton, Rotifera, Cladocera, and Copepoda biomass, respectively. The independent variables included in the model were: $\mathrm{Q}$ - water flow; $\mathrm{DO}$ - dissolved oxygen; $\mathrm{H}_{2} \mathrm{~S}$ - hydrogen sulphide; $\mathrm{SO}_{4}$ - sulphate; PO4-P - soluble reactive phosphorus. Probability levels of $t$-values for coefficients are denoted as follows: ${ }^{*} P<0.05, * * P<0.01 ;{ }^{1,2}$ site number.

\begin{tabular}{|c|c|c|c|c|c|c|c|c|}
\hline \multirow[b]{2}{*}{ Variable } & \multicolumn{5}{|c|}{ Coefficients } & \multicolumn{3}{|c|}{ Regression statistics } \\
\hline & Q & $\mathrm{P}-\mathrm{PO}_{4}$ & $\mathrm{SO}_{4}$ & $\mathrm{H}_{2} \mathrm{~S}$ & DO & $\mathrm{F}$ & $\mathrm{P}$ & $\mathrm{R}^{2}$ \\
\hline Ntot & $1.94 * *$ & & & & $0.47 *$ & ${ }^{2} 7.72$ & 0.021 & 0.720 \\
\hline $\mathrm{Nr}$ & $2.01 * *$ & & & & $0.40^{*}$ & ${ }^{2} 6.89$ & 0.027 & 0.69 \\
\hline \multicolumn{9}{|l|}{$\mathrm{Ncl}$} \\
\hline Ncp & & $-2.94 * *$ & & $-0.50 *$ & & ${ }^{2} 11.50$ & 0.004 & 0.74 \\
\hline Btot & & $-0.59^{*}$ & & & & ${ }^{1} 5.37$ & 0.04 & 0.35 \\
\hline \multicolumn{9}{|l|}{$\mathrm{Br}$} \\
\hline \multicolumn{9}{|l|}{$\mathrm{Bcl}$} \\
\hline $\mathrm{Bcp}$ & & $-4.05^{* *}$ & $-1.97 *$ & & & ${ }^{2} 6.70$ & 0.023 & 0.667 \\
\hline
\end{tabular}

cladocerans, was small, even though cladocerans of the genera Daphnia, Diaphanosoma, Chydorus, and Bosmina occurred abundantly in the Lake Kortowskie epilimnion during the study period (unpublished data). Cladocera are a thermophilic form, and they commonly inhabit surface water layers in lakes. Under natural conditions, this is why in the initial outflow zones of rivers from lakes are often inhabited by typically pelagic species of the genera Daphnia and Diaphanosoma, which are gradually replaced by typical ubiquitous riverine species of the genera Bosmina or Chydorus (Ejsmont-Karabin, Węgleńska, 1996; Bowszys, 2004). Only a few individuals of the species $B$. longirostris were noted to occur in the Kortówka River. This could have resulted from cladocerans being eliminated from mechanical injuries sustained from turbulent water flow through the pipeline or by the effect of sediment resuspension in the zone where the river is supplied with hypolimnion waters. Both water flow turbulence and suspended mineral content in waters negatively impact Cladocera (e.g., Wahl et al., 2008; Tóth et al., 2011). Besides, cladocerans usually do not occur in the deep lake water layers that were discharged into the river artificially. Among copepods, the abundant occurrence of their juvenile forms was noted in the river studied. Copepodites and nauplii are organisms that are more resistant to hydraulic stress, and they often dominate the potamoplankton (e.g. Mitsuka and Henry, 2002). Among adult Copepoda, M. leuckarti and T. oithonoides were confirmed in the Kortówka River zooplankton. These taxa are two of the three copepod species that occurred in the Lake Kortowskie plankton during the study (unpublished data). M. leuckarti and T. oithonoides inhabit not only lake surface waters, but they are also noted in the metalimnion and even the near-bottom layers of deep, stratified lakes (Nielsen and Wærwågen, 2000). Therefore, they could have flowed into the Kortowka River along with the hypolimnetic waters discharged through the pipeline, or with the surface water outflow.

In Lake Kortowskie and the Kortówka River that flows out from it, the similarity of fauna between the zooplankton communities inhabiting the two environments was low at $30-40 \%$. Low Jaccard index values were obtained when comparing the zooplankton communities of the river and the lake epilimnion and also those of the river and the lake hypolimnion. This is evidence of the substantial mixing of lake surface and hypolimnion waters at the outflow into the river and the rapid transformation of a totally different biocenosis. Under natural conditions, the fauna of zooplankton communities in lake outflow zones is highly similar (70-80\%) to that of pelagic epilimnion zones (Ejsmont-Karabin and Węgleńska, 1996). The results of our study demonstrated that artificially draining hypolimnion waters into the river caused substantial mixing of lake surface and hypolimnion waters at the river outflow area and disrupted the natural process of transforming communities of aquatic organisms.

\subsection{Zooplankton abundance and biomass}

The mean zooplankton abundance was low at the sites in the river studied at approximately $150-170$ indiv. $\mathrm{L}^{-1}$. This range of values was in excess of ten times lower that that noted in the same period in Lake Kortowskie. Significant decreases in zooplankton abundance were detected even at the pipeline discharge. Along the river course, only a slight, insignificant decease in overall zooplankton abundance was observed in the segment from the river outflow from the lake to the site located $500 \mathrm{~m}$ downstream. In natural lake-river systems, significant reductions in the abundance of planktic organisms occurs at a distance of several hundred meters from the river outflow zones from lakes. Ejsmont-Karabin and Węgleńska (1996) observed a near ten-fold decrease in zooplankton abundance in different rivers of the Krutynia River lake-river system in the 200-500 m segments downstream from their lake outflows. According to these authors, the loss of planktic organisms depended on, inter alia, the oxygen content of the water, the intensity of the turbulence of the flowing water in the river, and the trophic status of the lakes from which the rivers flowed. In the Kortówka River, zooplankton abundance was already reduced at the pipeline discharge because of the selective impact the pipeline had on planktic organisms. The lack of any distinct reductions in the abundance of organisms along river course can be explained by the fact that, as a result of pipeline operation, more resistant species dominate the biocenosis and 
pass through the pipeline uninjured, and these are more resistant to the hydraulic stress of the environment shifting from limnetic to riverine.

From an ecological point of view, the significant decrease in zooplankton abundance in the Kortówka River relative to that in the lake was a negative phenomenon. Additionally, one of the consequences of the distinct domination of small-sized planktic rotifers in the zooplankton community was the low zooplankton biomass in the Kortówka River waters flowing out of the lake. High zooplankton density and biomass in river waters flowing out of lakes is desirable because of the significance of riverine zooplankton in downstream food webs (Akopian et al., 1999; Wallace and Hutchens, 2000; Jack and Thorp, 2002).

On the other hand, the zooplankton density flowing out of Lake Kortowskie with Kortówka River waters is currently several-fold higher than when the pipeline was operating at full capacity. Studies from 1986-1987 (Borgul, 1988; Waligóra, 1988) indicated that in the period from July to October zooplankton density at the pipeline outflow site fluctuated within a range of $10-70$ indiv. $\mathrm{L}^{-1}$ at a water flow rate range of $40-260 \mathrm{~L} \mathrm{~s}^{-1}$. In 2013, the zooplankton density noted in this same period fluctuated within a range of $35-430$ indiv. $\mathrm{L}^{-1}$, while the water flow rate fluctuated from 2 to $80 \mathrm{~L} \mathrm{~s}^{-1}$. Differences in zooplankton abundance resulted from the fact that in the 1980s the water discharged into the river was mainly from the hypolimnion, which was less rich in zooplankton than was the lake surface water layer. Modifications to pipeline operation include shortening its operating time in the summer-fall period while simultaneously increasing the percentage share of the surface layer waters in the outflow (Dunalska et al., 2007; Tandyrak et al., 2016), thus minimizing the negative ecological impact of lake restoration that is based on reducing zooplankton abundance. This is how lake restoration is made more sustainable in terms of its environmental impact.

\subsection{Environmental parameters and their impact on zooplankton}

Water flow was found to be the best predictor of the total density of zooplankton and rotifers, the taxonomic group which was the most abundant component of the community studied. The relationship between water flow and zooplankton was positive. While increased water flow in the river might have a negative impact on zooplankton, mainly on crustaceans (e.g., Viroux, 2002), similarly to our study, other authors have noted the opposite relationship (Nielsen et al., 2005; Czarniawski and Domagała, 2010). This discrepancy in results suggest that the impact of water flow on zooplankton might depend on local conditions. The phenomenon occurring in lake-river systems is that river ecosystems are fortified with zooplankton-rich lake waters (Ejsmont-Karabin and Węgleńska, 1996), and when water flow increases we can anticipate increased organism drift in rivers. This is also why there might be a positive relationship between water flow rates in the river and zooplankton abundance, which simultaneously underscores the role of the supplementing the Kortówka River with surface layer waters from Lake Kortowskie and compensating for the negative impact of the artificial inflow of hypolimnion waters from the lake.
Discharging deep layer waters from lakes as a restoration method has an impact on water quality in recipient streams. The implications of this method can be compared to damming rivers and the release of hypolimnetic waters. Numerous studies on the effects of this type of damming on riverine ecosystems downstream from dams report disadvantageous environmental conditions, including, primarily, oxygen deficits, substantial amounts of organic matter and the associated high biological oxygen demand, and increased contents of nutrients, heavy metals, etc. (review by Austin et al., 2015).

Hypoxia, which occurs when the dissolved oxygen content in water decreases below $2 \mathrm{mg} \mathrm{L}^{-1}$, is an increasingly common phenomenon in the hypolimnion of eutrophic lakes. It was also recorded in deep layers of Lake Kortowskie (Dunalska, 2003). Oxygen deficits of this magnitude are harmful to most aquatic organisms (Diaz, 2011; Diaz and Rosenberg, 2008). During the present study, the dissolved oxygen concentration noted in the Kortówka River was very low periodically $\left(2 \mathrm{mg} \mathrm{L}^{-1}\right)$, but it never exceeded the limits for hypoxia. This can be attributed to the refreshing influence of the well-oxygenated waters the river received from the surface layer of the lake. Consequently, both zooplankton density (total, rotifers and copepods) and biomass (copepods) were positively linked with the content of dissolved oxygen in the water, as confirmed by the results of multiple regression and correlation calculations. Simultaneously, the negative impact of hydrogen sulphide and sulphates on copepods was also observed. The occurrence of hydrogen sulphide is linked with decreased oxygen contents in the water. As Tandyrak et al. (2016) demonstrated, these two parameters were significantly, inversely correlated in the Kortówka River. The occurrence of hydrogen sulphide in the waters of the studied river could have come from the deoxygenated, deep layers of the lake. The surface sediments of lakes, which contain large amounts of freshly deposited planktic organic compounds, are very important in the production of hydrogen sulphide by sulphate reducing bacteria (Holmer and Stolkholm, 2001). Copepoda can inhabit deoxygenated hypolimnion waters since their juvenile stages utilize hypoxic water as a refuge from predators despite the negative impact it has on their abundance (Elliot et al., 2013). Thus, it is possible that the negative impact sulphur compounds had on copepod abundance in the waters of the Kortówka River was an effect of dependencies occurring in the lake hypolimnion that were also observed in the initial segment of the river where hydrogen sulphide was still present in the environment.

The Spearman rank correlations calculated in the present study indicated that there was a positive relationship between total organic carbon content and copepod biomass and density. The Lake Kortowskie waters discharged through the pipeline are rich in organic matter (Dunalska, 2007). Tandyrak et al. (2016) demonstrated that the organic matter content positively impacted total bacterial abundance in the waters of the Kortówka River. One of the mechanisms regulating bacterial abundance in aquatic ecosystems is Copepoda trophic activity based on organic matter availability and the heterotrophic bacteria-bacterivorous protozoa-copepod pathway or on copepods directly consuming bacteria (Stoecker and Capuzzo, 1990). Thus, it is likely that juvenile copepods occurring abundantly in the waters of the Kortówka River, which are considered to be bacterivorous 
(Kim et al., 2000), exploit the heterotrophic food chain and the abundance of bacteria in the environment. This thesis offers a good explanation for the relationships described in this paper between the content of organic carbon in the water and copepods.

Our results obtained from multiple regression and Spearman rank correlations indicated the negative impact of the soluble reactive phosphorus content on total zooplankton biomass and copepod abundance and biomass. Soluble reactive phosphorus is a readily available form of this elemental nutrient to primary producers, and it is easily incorporated into the biomass of phytoplankton. The positive relationship between soluble reactive phosphorus and zooplankton is indirect evidence of zooplankton utilizing phytoplankton in the autotrophic food chain. The opposite relationship with the simultaneous existence of a positive relationship between the content of organic carbon and zooplankton might indicate the occurrence of a heterotrophic pathway (e.g., Conde-Porcuna et al., 2002; Bowszys et al., 2014). Therefore, it seems that the functioning of the zooplankton communities in the river studied depended largely on the heterotrophic food chain.

It must be underscored that nearly all the relationships described above between environmental conditions and zooplankton were observed at the site that was located farther downstream from the pipeline. This suggests that the powerful interference with the natural continuity of the lake-river system destabilizes the environment to such an extent that there are no distinct relationships between the prevailing physicochemical conditions in the river and zooplankton in the initial segment of the river.

The outcomes of the present study clearly demonstrated that restoring Lake Kortowskie by draining hypolimnion waters into the river flowing out of the lake impacted the riverine biocenosis. The river zooplankton was dominated by rotifers and juvenile copepods, which are more resistant to hydraulic stress than the other zooplankton items analyzed. Zooplankton abundance in the river studied was strongly reduced in comparison to that in the lake out of which the river flowed even near the discharge site. However, further distinct reductions in the abundance of organisms along the course of the river were not observed. The pipeline modified environmental conditions in the recipient river that affected zooplankton significantly. Among the environmental variables analyzed, water flow and soluble reactive phosphorous were the main predictors of zooplankton density and biomass.

Since many lakes worldwide are being restored with this method, the observations in this paper can be helpful in managing lakes of this type. The results of our study can be used to improve this restoration method and to minimize the negative impact of technical measures on the downstream river environment.

Acknowledgments. We wanted to thank to Daniel Szymański $(\mathrm{PhD})$ for water samples collection and Magda Stypułkowska for her assistance with zooplankton sampling in field and samples preparation for further determination. This study was supported by grants No 18.610.007-300 and 528-0807-0806 from the Ministry of Science and Higher Education (Poland).

\section{References}

Akopian M, Garnier J, Pourriot RA. 1999. Large reservoir as a source of zooplankton for the river: structure of the populations and influence of fish predation. J Plankton Res 21: 285-297.

Austin H, Bradley D, Stewart-Russon I, Milner N. 2015. Literature review of the influence of large impoundments on downstream temperature, water quality and ecology, with reference to the Water Framework Directive Scottish Environmental Protection Agency. March 2015 - sepa.org.uk.pdf.

Błędzki LA, Rybak JI. 2016. Freshwater crustacean zooplankton of Europe: Cladocera \& Copepoda (Calanoida, Cyclopoida). Key to species identification with notes on ecology, distribution, methods and introduction to data analysis. Springer, $918 \mathrm{p}$.

Borgul L. 1988. Zooplankton skorupiakowy (Crustacea) wynoszony rurociągiem i rzeką Kortówką z Jeziora Kortowskiego w latach 1986-1987. Katedra Biologii Wody i Ścieków ART Olsztyn. (manuscript).

Bottrell HH, Duncan A, Gliwicz ZM, et al. 1976. A review of some problems in zooplankton production studies. Norw J Zool 24: 419-456.

Bowszys M. 2004. The effect of impoundment and environmental factors on zooplankton of the Pierzchalski Dam Reservoir. Pol J Natur Sci 17: 405-423.

Bowszys M, Dunalska JA, Jaworska B. 2014. Zooplankton response to organic carbon level in lakes of differing trophic states. Knowl Manag Aquat Ecosyst 412: 10.

Chudyba H. 1996. Batrachospermum moniliforme Roth i glony towarzyszące w rzece Kortówce w Olsztynie. Acta Academiae Agriculturae ac Technicae Olstenensis Protectio Acuarum et Piscatoria 22: 95-108.

Clesceri LS, Greenberg AE, Eaton AD. 1998. Standard methods for the examination of water and wastewater, 20th edn. Washington, DC: American Public Health Association, 1325 p.

Conde-Porcuna JM, Ramos-Rodriguez E, Perez-Martinez C. 2002. Correlations between nutrient concentrations and zooplankton populations in a mesotrophic reservoir. Freshw Biol 47: 1463-1473.

Czarniawski R, Domagała J. 2010. Zooplankton communities of two lake outlets in relation to abiotic factors. Cent Eur J Biol 5: 240-255.

Diaz RJ. 2011. Overview of hypoxia around the world. $J$ Environ Qual 30: 275-281

Diaz RJ, Rosenberg R. 2008. Spreading dead zones and consequences for marine ecosystems. Science 321: 926-929.

Dunalska J. 2001. Effect of limited hypolimnetic withdrawal on the content of nitrogen and phosphorus in the waters of Kortowskie Lake. J Natur Sci 9: 333-345.

Dunalska J. 2003. Impact of limited water flow in a pipeline on the thermal and oxygen conditions in a Lake restored by hypolimnetic withdrawal method. Pol J Env Stud 12: 409-415.

Dunalska J, Wiśniewski G, Mientki C. 2007. Assessment of multi-year (1956-2003) hypolimnetic withdrawal from Lake Kortowskie, Poland. Lake Reserv Manag 23: 377-387.

Ejsmont-Karabin J. 1998. Empirical equations for biomass calculation of planktonic rotifers. Pol Arch Hydrobiol 45: 513-522.

Ejsmont-Karabin J, Radwan S, Bielańska-Grajner I. 2004. Monogonta - atlas gatunków. 32B. In: Radwan S, ed. Wrotki (Rotifera). Fauna słodkowodna Polski. 32. Polskie Towarzystwo Hydrobiologiczne, Uniwersytet Łódzki. Oficyna Wydawnicza Tercja, Łódź., 447 p. 
Ejsmont-Karabin J, Węgleńska T. 1996. Przemiany struktury zooplanktonu w strefach przejściowych rzeka-jezioro-rzeka (system rzeki Krutyni, Pojezierze Mazurskie). Zeszyty Naukowe PAN Człowiek i Środowisko 13: 263-289.

Elliot D, Pierson JJ, Roman RM. 2013. Copepods and hypoxia in Chesapeake Bay: abundance, vertical position and non-predatory mortality. J Plankton Res 35: 1027-1034.

Flössner D. 1972. Krebstiere, Crustacea. Kiemen-und Blattfüsser, Branchiopoda, Fischläuse, Branchiura. Jena: VEB Gustav Fischer Verlag, $382 \mathrm{p}$.

Gołdyn R, Podsiadłowski S, Dondajewska R, Kozak A. 2014. The sustainable restoration of lakes - towards the challenges of the Water Framework Directive. Ecohydrol Hydrobiol 14: 68-74.

Hermanowicz W, Dojlido J, Zerbe J, Dołżańska W, Koziorowski B. 1999. Physico-chemical analyses of water and wastewater. Warszawa: Arkady, 555 p.

Holmer M, Stolkholm P. 2001. Sulphate reduction and sulphur cycling in lake sediments: a review. Freshw Biol 46: 431-451.

Jaccard P. 1912. The distribution of the flora of the alpine zone. New Phytolog 11: 37-50.

Jack JD, Thorp JH. 2002. Impacts of fish predation on an Ohio River zooplankton community. J Plankton Res 24: 119-127.

Jaworska B, Dunalska J, Górniak D, Bowszys M. 2014a. Phytoplankton dominance structure and abundance as indicators of the trophic status and ecological state of Lake Kortowskie (northeast Poland) restored with selective hypolimnetic withdrawal. Arch Pol Fish 22: 7-15.

Jaworska B, Zdanowski B, Bowszys M, Koszałka J. 2014b. Wpływ dominacji i stałości występowania sinic na mechanizm zmian struktury fitoplanktonu w Jeziorze Kortowskim. Ochr Sr 36: 15-22.

Kasprzak K, Niedbała W. 1981. Biocenotic indices in quantitative study. In Górny M, Grüm L, eds. Methods applied in soil zoology. Warsaw: PWN, 397-416.

Kim H-W, Hwang S-J, Joo G-J. 2000. Zooplankton grazing on bacteria and phytoplankton in a regulated large river (Nakdong River, Korea). J Plankton Res 22: 1559-1577.

Koste W. 1978. Rotatoria. Die Rädertiere Mitteleuropas. Überordnung Monogononta. I Textband, II Tafelband. Berlin: Gebrüder Borntraeger, $570 \mathrm{p}$.

Kumar A. 2008. Hypolimnic withdrawal for lake conservation. In Sengupta M, Dalwani R, eds. Proceedings of Taal 2007: the 12th World Lake Conference, 812-818.

Lehman EM, McDonald KE, Lehman JT. 2009. Whole lake selective withdrawal experiment to control harmful cyanobacteria in an urban impoundment. Water Res 43: 1187-1198

Marshall DW, Otto M, Panuska JC, Jaeger SR, Sefton D, Baumberger TR. 2006. Effects of hypolimnetic releases on two impoundments and their receiving streams in southwest Wisconsin. Lake Reserv Manag 22: 223-232.

Mientki Cz. 1997. Chemical properties of Kortowskie Lake waters after 18 years experiment on its restoration. Part III. Dynamics of phosphorus compounds. Pol Arch Hydrobiol 24: 25-35.
Mitsuka PM, Henry R. 2002. The fate of copepod populations in the Paranapanema River (São Paulo, Brazil), downstream from the Jurumirim dam. Braz Arch. Biol technol 45: 479-490.

Nielsen JP, Wærwågen SB. 2000. Superficial ecosystem similarities vs autecological stripping: the "twin species" Mesocyclops leuckarti (Claus) and Thermocyclops oithonoides (Sars) - seasonal habitat utilisation and life history traits. J Limnol 592: 79-102.

Nielsen D, Watson G, Petrie R. 2005. Microfauna communities in three lowland rivers under differing flow regimes. Hydrobiologia 543: 101-111.

Nürnberg GK. 1987. Hypolimnetic withdrawal as lake restoration technique. J Environ Eng 113: 1006-1017.

Nürnberg GK. 2007. Lake responses to long-term hypolimnetic withdrawal treatments. Lake Reserv Manag 23: 300-409.

Olszewski P. 1971. Dotychczasowe wyniki eksperymentu nad odmładzaniem Jeziora Kortowskiego. Zesz Nauk WSR Olszt 3: 23.

Pietrzak L. 2004. Wpływ krajobrazu zurbanizowanego na kształtowanie się zgrupowań larw chruścików (Trichoptera) na przykładzie Olsztyna i Złocieńca. Katedra Ekologii Ewolucyjnej UWM Olsztyn. PhD Thesis. http://www.uwm.edu.pl/czachor/publik/ pdf-inne/Pietrzak.pdf.

Ruttner-Kolisko A. 1977. Suggestions for biomass calculations of plankton rotifers. Arch Hydrobiol Beih Ergebn Limnol 8: 71-76.

Rybak JI, Błędzki LA. 2010. Freshwater planktonic crustaceans. Warsaw: Warsaw University Press, 307 p.

Stoecker DK, Capuzzo JM. 1990. Predation on protozoa: its importance to zooplankton. J Plankton Res 12: 891-908.

Tandyrak R, Gołaś I, Parszuto K, et al. 2016. The effect of lake restoration by the hypolimnetic withdrawal method on the intensity of ambient odour. J Limnol 75: 531-544.

Tischler M. 1949. Grundzuge der terristrischen Tierokologie. Braunschweig (cited from Wallwork, 1976)

Tóth LG, Parpala L, Balogh C, Tátrai I, Baranyaia E. 2011. Zooplankton community response to enhanced turbulence generated by water-level decrease in Lake Balaton, the largest shallow lake in Central Europe. Limnol Oceanogr 56: 2211-2222.

Viroux L. 2002. Seasonal and longitudinal aspects of microcrustacean (Cladocera, Copepoda) dynamics in a lowland river. J Plankton Res 24: 281-292.

Wahl DH, Goodrich J, Nannini MA, Dettmers JM, Soluk DA. 2008. Exploring riverine zooplankton in three habitats of the Illinois River ecosystem: where do they come from? Limnol Oceanogr 53: 2583-2593.

Waligóra B. 1988. Wrotki planktonowe (Rotatoria) wynoszone rurociągiem z Jeziora Kortowskiego i rzeką Kortówką w latach 1986-1987. Katedra Biologii Wody i Ścieków ART Olsztyn (manuscript).

Wallace JB, Hutchens JJ. 2000. Effects of invertebrates in lotic ecosystem process. In Eds: Coleman DC, Hendrix PF, eds. Invertebrates as webmasters in ecosystems. Oxon: CABI Publishing, 73-96.

Cite this article as: Bowszys M, Tandyrak R, Gołaś I, Paturej E. 2020. Zooplankton communities in a river downstream from a lake restored with hypolimnetic withdrawal. Knowl. Manag. Aquat. Ecosyst., 421, 12. 